\title{
Modified Densification Process for Increasing Strength Properties of Pine and Gmelina Wood from Community Forests ${ }^{1}$
}

\author{
Andi Detti Yunianti $\mathbb{D}^{2, \dagger} \cdot$ Kidung Tirtayasa P. ${ }^{3} \cdot$ Suhasman $^{2} \cdot$ Ira $^{\text {Taskirawati }}{ }^{2} \cdot$ \\ Agussalim $^{2} \cdot$ Musrizal Muin ${ }^{2}$
}

\begin{abstract}
Densification is a process for improving the strength properties of wood from the felling of young trees, which is a common harvest practice in community forests. A series of experiments was conducted to refine the process with particular regard to the determination of suitable pretreatment and treatment conditions. Samples of pine and gmelina measuring $23 \mathrm{~cm}(\mathrm{~L}) \times 20 \mathrm{~cm}(\mathrm{~W}) \times 2 \mathrm{~cm}(\mathrm{~T})$ underwent pretreatment through immersion in a $1: 1$ $\mathrm{CH}_{3} \mathrm{COOH}-\mathrm{H}_{2} \mathrm{O}_{2}$ solution at concentrations of $15 \%$, 20\%, and $30 \%$. Samples pretreated with the $20 \%$ solution showed the greatest improvement in strength; further experiments were conducted to determine the optimum treatment conditions in terms of temperature and duration following immersion. Test samples with the same dimensions as those in the pretreatment experiment were soaked in a $1: 120 \% \mathrm{CH}_{3} \mathrm{COOH}-\mathrm{H}_{2} \mathrm{O}_{2}$ solution and warmed in a water bath. The test samples were then individually hot pressed to the target thickness, which was $30 \%$ less than the original thickness and held at $150^{\circ} \mathrm{C}$ or $170^{\circ} \mathrm{C}$ for 15 or 30 minutes. The treated samples were cut for an analysis of their density, recovery of set, and bending strength. Pine and gmelina exhibited the best characteristics after treatment at $150^{\circ} \mathrm{C}$ for 30 and 15 minutes, respectively. The results suggest that the modified densification process had increased the bending strength of the wood, but the temperature and duration of treatment must be carefully considered for different wood species.
\end{abstract}

Keywords: bending strength, community forest, wood densification, recovery of set

\section{INTRODUCTION}

\subsection{Background}

Trees felled at a young age, which is a common harvest practice in community forest, produce wood with inferior characteritics. This wood usually needs to be treated to meets requirements for structural uses. Densification of wood through a compression process has proved to increase wood density and strength, which translate to improved surface hardness, bending strength, and dimension stability due to decreased porosity (Danu et al., 2013; Tomme et al., 1998; Hill, 2011). Moreover,

\footnotetext{
${ }^{1}$ Date Received March 9, 2019, Date Accepted July 3, 2019

2 Faculty of Forestry, Hasanuddin University, Perintis Kemerdekaan Km. 10 Makassar, Indonesia

${ }^{3}$ Faculty of Forestry, Bogor Agricultural Institute, Darmaga Road, IPB Darmaga Campus, Bogor 16680, West Java, Indonesia

† Corresponding author: Andi Detti Yunianti (e-mail: dettiyunianti70@yahoo.com, ORCID: 0000-0002-7087-9589)
} 
Modified Densification Process for Increasing Strength Properties of Pine and Gmelina Wood from Community Forests

Nestri (2014) reported that densification enables increased density, specific gravity, modulus of elasticity (MOE), and modulus of rupture (MOR) of wood from fast-growing species.

The effectiveness of wood densification mainly depends on treatment conditions, the wood species, and initial treatment, all of which can be modified (Wahyudi, 2013). Densification has been reported to be suitable for fast-growing species such as Agathis alba (Sulistyono et al., 2003), Ceiba pentandra (Krisdianto and Balfas, 2005), Cocos nucifera (Krisdianto, 2006), Enterolobium cyclocarpum, Maesopsis eminii, and Durio sp. (Ratih et al., 2009), as well monocotyl such as oil palm (Hartono et al., 2016). Initial treatments influencing wood modification high temperature treatment (Amin and Dwianto, 2006), particularly heating at temperatures of $170{ }^{\circ} \mathrm{C}$ and $220^{\circ} \mathrm{C}$ (Inoue et al., 2008), using a heated cooking compartment (Ratih et al., 2009), and using high- temperature immersion (Phebryanti, 2015) and different thermal compression durations (60 minutes and 90 minutes) with several condition (Lee and Lee, 2018).

The current study centers on the application of an initial treatment with a $\mathrm{CH}_{3} \mathrm{COOH}-\mathrm{H}_{2} \mathrm{O}_{2}$ solution prior to densification. The is solution has been found to be effective in the maceration process due to its ability to separate wood fibers and weaken wood lignin compound at a concentration of 100\% (Frans, 2013). Use of the mixture at lower concentrations is still expected to weaken the fiber bond and therefore, be suitable for immersing wood before densification. A preliminary study (unpublished data) showed that an initial treatment using a $\mathrm{CH}_{3} \mathrm{COOH}-\mathrm{H}_{2} \mathrm{O}_{2}$ solution at concentrations of $25 \%$ and $50 \%$ tended to decrease the wood strength. A lower concentration was expected to overcome this limitation in further study.

The current study was aimed at developing a densification process involving an initial treatment with $\mathrm{CH}_{3} \mathrm{COOH}-\mathrm{H}_{2} \mathrm{O}_{2}$ in water solution. The modified densification process, including optimal pre-treatment and treatment conditions, was expected to result in wood products with high density and strength properties.

\section{MATERIALS and METHODS}

\subsection{Sample preparation}

Commercially available boards of Pinus merkusii and Gmelina arborea with the size of $100 \mathrm{~cm} \times 20 \mathrm{~cm}$ $\times 2 \mathrm{~cm}$ were purchased for sample preparation. The fast-growing species from community forest had around ten years and growth ring about $2.25 \mathrm{~cm}$ per year. Five boards for each species were cut into four parts each for samples measuring $23 \mathrm{~cm}$ (Length) $\times 20 \mathrm{~cm}$ (Width) $\times 2 \mathrm{~cm}$ (Thickness). Mixtures of $\mathrm{CH}_{3} \mathrm{COOH}-\mathrm{H}_{2} \mathrm{O}_{2}$ at a ratio of $1: 1(\mathrm{v} / \mathrm{v})$ were diluted to three different concentrations in distilled water (15\%, 20\%, and 30\%) to prepare pretreatment solutions. Following immersion, three parts from boards for each species were densification process and one part for control. The steps for wood sample preparation are shown in Fig. 1.

\subsection{Immersion and densification process}

Immersion was conducted as a pre-treatment before densification by soaking the prepared samples in the $\mathrm{CH}_{3} \mathrm{COOH}-\mathrm{H}_{2} \mathrm{O}_{2}$ solutions at different concentrations and warming on water bath at temperature of $80^{\circ} \mathrm{C}$ for 24 hours. The pre-treated samples were then cooled in a desiccator for 15 minutes before densification.

Densification was performed by pressingthe wood samples to a targeted thickness of $30 \%$ of the original thickness by using a pressure level of $35 \mathrm{~kg} / \mathrm{cm}^{2}$ at $150^{\circ} \mathrm{C}$ and maintaining these conditions for 15 minutes. After ward, all samples were conditioned in a desiccator for 24 hours prior to testing. As shown in Fig. 2, the treated material was then cut into sample sizes of $2 \mathrm{~cm} \times 2 \mathrm{~cm} \times 1.4 \mathrm{~cm} \mathrm{(a),} 10 \mathrm{~cm} \times 2 \mathrm{~cm} \times 1.4 \mathrm{~cm}$ (b), and $23 \mathrm{~cm} \times 1.4 \mathrm{~cm} \times 1.4 \mathrm{~cm}$ (c) to determine density, 


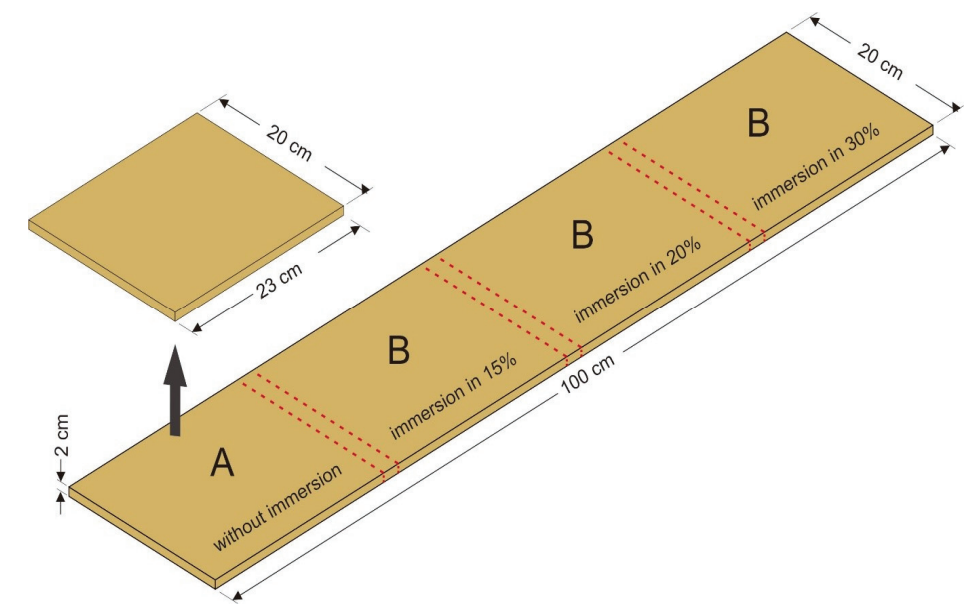

Fig. 1. Sample preparation (A, control; B, for densification).

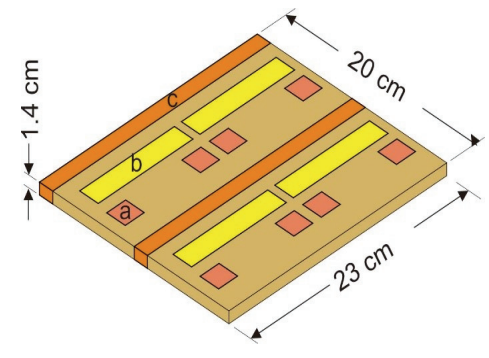

Fig. 2. Sample sizes for density (a), recovery of set (b), and bending strength (c).

recovery of set, and bending strength, respectively, of wood. All untreated and treated samples were tested for their physical properties (density and recovery of set) and mechanical properties (MOE and MOR) according to British Standard Methods no. 373 (1957) and modified ASTM D 143-94 (2005), respectively. The recovery of set is a decrease of the thickness after densification applied - expressed in percentage. It was determined by measuring the thickness of the sample at before immersion and after densification treatments. Meanwhile, static bending test was conducted to determine MOE and MOR. This test used centre loading and a modified span length of $19.6 \mathrm{~cm}$ based on the sample size.

\section{RESULTS and DISCUSSION}

\subsection{Density and set recovery changes before and after densification}

\subsubsection{Density}

The density changes of pine wood and gmelina wood samples before and after densification following immersion in various concentrations of a $\mathrm{CH}_{3} \mathrm{COOH}-\mathrm{H}_{2} \mathrm{O}_{2}$ solution are shown in Fig. 3. The densification after pretreatment by immersion at a lower concentration of the solution resulted in higher densities of the two treated wood species. Pre-treatment with the higher concentration was found to decrease the density of the samples.

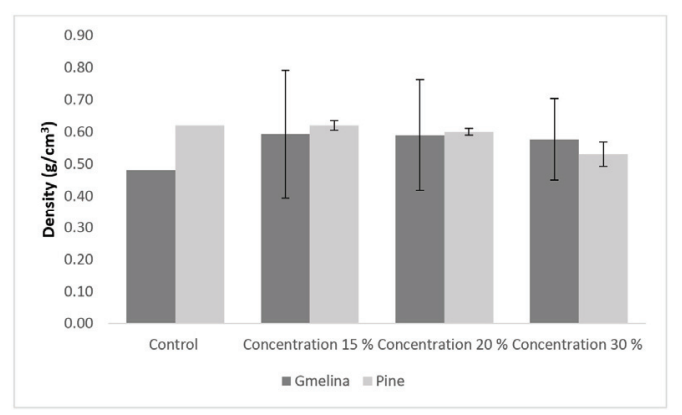

Fig. 3. Density changes of gmelina and pine wood. 
According to Frans (2013), $\mathrm{H}_{2} \mathrm{O}_{2}$ and $\mathrm{CH}_{3} \mathrm{COOH}$ can separate the fibers that are in the wood and can soften the wood. It is expected to change the shape and frequency of some types of cells wood. These changes make wood from densification process easy to be modified its density. Hartono et al. (2016), density from oil palm trunk increased by $3.33 \%-90 \%$, one of the contributing factors is anatomical structure change from round and intact, become after densification treatment they showed flattened shapes.

Densification involves softening the wood lignin through heating, which weakens the wood fiber bonds and makes the cell walls more plastic. Pressure subsequently applied to the wood may result in cell deformation, leading to the easy binding and fixation of collapsed cells (Sulistyono et al., 2003). This transformation of wood cells increases the overall wood density. The lower density of the densified wood after pre-treatment at higher concentrations of $\mathrm{CH}_{3} \mathrm{COOH}$ $\mathrm{H}_{2} \mathrm{O}_{2}$, particularly at $30 \%$, seems to correlate with the presence of broken or separate cells that are difficult to bind or fix.

\subsubsection{Recovery of Set}

After compression, the deformed wood material was sensitive to moisture and recovered at different levels of the deformation in water-soaking. Changes in the recovery of set of deformed pine wood and gmelina wood samples before and after densification following immersion $\mathrm{CH}_{3} \mathrm{COOH}-\mathrm{H}_{2} \mathrm{O}_{2}$ solutions at different concentrations are shown in Table 1 .
Table 1 shows that recovery of set of pine wood is smaller than that of gmelina wood, indicating that gmelina wood is easier to change into primary shape compared to pine wood. The higher the recovery of set value, the more easily the wood returns to its original shape, meaning that the deformed wood material cannot be properly fixed. However, our results show that the immersion and densification of the two wood species yielded permanent fixation levels as indicated by the recovery of set value of less than 20\% (Wahyuni et al., 2012). The higher recovery of set value of gmelina wood compared to pine wood is due to its lower specific gravity and consequently, chemical properties that have been entered is very much but less binding with chemical properties on cell wall. Furthermore, pine wood, which is classified as a softwood, has a uniform cell type, and consistent thickness of cell walls, and is thus able to binding with chemical properties on cell walls. (Panshin and de Zeuuw, 1989).

Densification process without any additional treatment typically does not yield a permanent set (Kutnar and Sernek, 2007). The wood can return to its original thickness as it is exposed to humidity or moisture. This springback characteristic can be addressed through heating treatment and resin impregnation, which are adequate for reducing stress on wood and building new crosswise binding between cell walls (Rautkari, 2011). Additional initial treatments could soften lignin and strengthen the bonds between fibers depending on the temperature, time and concentration.

Table 1. Recovery of set of pine wood and gmelina wood after the densification process

\begin{tabular}{cccc}
\hline \multirow{2}{*}{ Wood species } & \multicolumn{3}{c}{ Recovery of Set (\%) after immersion in $\mathrm{CH}_{3} \mathrm{COOH}-\mathrm{H}_{2} \mathrm{O}_{2}$ at } \\
& $15 \%$ & $20 \%$ & $30 \%$ \\
\cline { 2 - 4 } & $4.72 \pm 0.33$ & $3.20 \pm 0.07$ & $6.83 \pm 1.36$ \\
\hline \hline Pine & 4.720 concentrations* & $18.42 \pm 2.87$ \\
Gmelina & $14.04 \pm 2.56$ & $12.27 \pm 0.67$ & \\
\hline
\end{tabular}

* Average and standard deviation of five replicates 


\subsection{Changes in (MOE) and (MOR) before and after densification}

Results for the bending strength (MOE and MOR) of pine wood and gmelina wood samples before and after densification following immersion in different concentrations of $\mathrm{CH}_{3} \mathrm{COOH}-\mathrm{H}_{2} \mathrm{O}_{2}$ solution are shown in Fig. 4 and Fig. 5.

MOR before and after densification with pretreatment that is immersion of wood samples in $\mathrm{CH}_{3} \mathrm{COOH}-\mathrm{H}_{2} \mathrm{O}_{2}$ solution at concentrations of $15 \%, 20 \%$ and $30 \%$ presented in Fig. 5.

Figs. 4 and 5 show that MOE and MOR values of densified wood increased after pre-treatment with $\mathrm{CH}_{3} \mathrm{COOH}-\mathrm{H}_{2} \mathrm{O}_{2}$ solutions at the concentrations of $15 \%$ and $20 \%$, but tended to decrease when pre-treated with the higher concentration (30\%). The highest bending strength of densified wood was associated with pre-

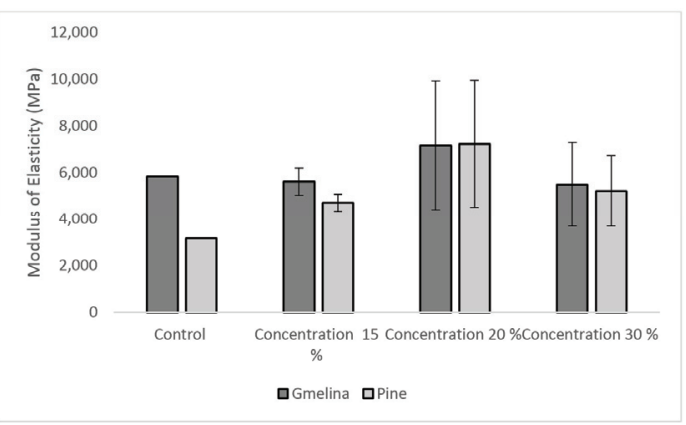

Fig. 4. MOE changes of gmelina and pine wood.

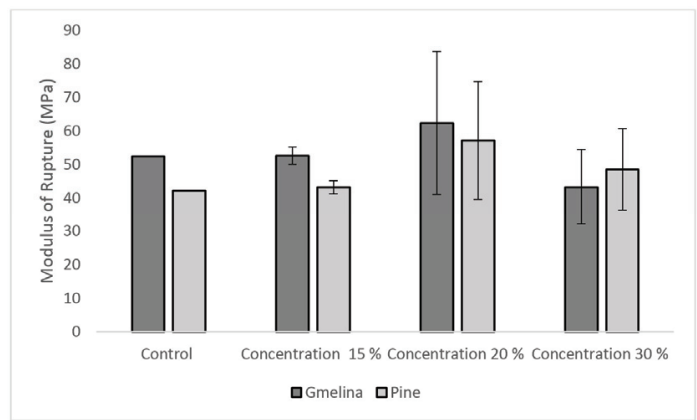

Figu. 5. MOR changes of gmelina and pine wood. treatment with the $20 \% \mathrm{CH}_{3} \mathrm{COOH}-\mathrm{H}_{2} \mathrm{O}_{2}$ solution. This result indicates that the stiffness of densified wood can be increased by pre-treatment in the form of immersing wood in a $\mathrm{CH}_{3} \mathrm{COOH}-\mathrm{H}_{2} \mathrm{O}_{2}$ solution at a concentration of $15 \%-30 \%$, but the wood potentially becomes brittle or easy to crack. Therefore, further research was conducted to determine the effect of the densification temperature $\left(150^{\circ} \mathrm{C}\right.$ and $\left.170^{\circ} \mathrm{C}\right)$ and duration (15 and 30 minutes) following pre-treatment with a $20 \%$ $\mathrm{CH}_{3} \mathrm{COOH}-\mathrm{H}_{2} \mathrm{O}_{2}$ solution. The results of these experiment are shown in Table 2.

Table 2 shows that the physical and mechanical properties of densified wood after immers in the $20 \%$ $\mathrm{CH}_{3} \mathrm{COOH}-\mathrm{H}_{2} \mathrm{O}_{2}$ solution differ according to the wood species and treatment conditions. The physical and mechanical properties of densified pine wood generally increased with time when the treatment temperature was $150^{\circ} \mathrm{C}$, but it tended to decrease at the treatment temperature of $170^{\circ} \mathrm{C}$. Meanwhile, increased treatment temperature and time almost decreased the bending properties of gmelina wood. This study showed that pretreatment immersion and densification at the temperature of $150^{\circ} \mathrm{C}$ for 30 minutes were suitable for pine wood, increasing its strength and stiffness. Likewise, immersion and a treatment temperature of $150^{\circ} \mathrm{Cwere}$ appropriate gmelina wood, but a treatment period of 15 minutes yielded better densification results. These results are related to the higher recovery of set for gmelina wood compared with pine wood. Application of a higher temperature of $180^{\circ} \mathrm{C}$ can destroy many wood structuralcells, decreasing the strength and stiffness of wood (Darwis et al., 2017). High temperature treatment following pre-treatment with immersion in $\mathrm{aCH}_{3} \mathrm{COOH}-\mathrm{H}_{2} \mathrm{O}_{2}$ solution can decomposed wood fibers and lignin. Densification is a wood compaction process, and pine wood is naturally more compact because its anatomical structure is more uniform (containing 90\% tracheid) than gmelina wood, which is more porous. In terms of treatment conditions, 
Table 2. Density, Recovery of Set, MOE and MOR of pine wood and gmelina wood as result of desification proccess carried out at various temperatures and lengths of time.

\begin{tabular}{cccccc}
\hline \multirow{2}{*}{ Tested } & \multirow{2}{*}{ Wood Species } & \multicolumn{2}{c}{ Temperature } & $150^{\circ} \mathrm{C}$ & \multicolumn{2}{c}{ Temperature $170^{\circ} \mathrm{C}$} \\
& & 15 minutes & 30 minutes & 15 minutes & 30 minutes \\
\hline \hline \multirow{2}{*}{ Density $\left(\mathrm{g} / \mathrm{cm}^{3}\right)$} & Pine & $0.67 \pm 0.01$ & $0.69 \pm 0.05$ & $0.73 \pm 0.06$ & $0.71 \pm 0.08$ \\
& Gmelina & $0.59 \pm 0.17$ & $0.49 \pm 0.06$ & $0.54 \pm 0.09$ & $0.55 \pm 0.06$ \\
\hline Recovery of & Pine & $3.20 \pm 0.07$ & $7.68 \pm 2.76$ & $8.91 \pm 3.34$ & $7.66 \pm 1.73$ \\
Set $(\%)$ & Gmelina & $12.27 \pm 0.67$ & $14.06 \pm 11.68$ & $17.22 \pm 9.19$ & $15.31 \pm 6.36$ \\
\hline \multirow{2}{*}{ MOE $(\mathrm{MPa})$} & Pine & $7,232 \pm 2,718$ & $11,198 \pm 1,505$ & $10,579 \pm 1,079$ & $8,433 \pm 672$ \\
& Gmelina & $7,162 \pm 2,757$ & $5,583 \pm 745$ & $6,499 \pm 1,707$ & $7,329 \pm 1,129$ \\
\hline \multirow{2}{*}{ MOR (MPa) } & Pine & $57 \pm 18$ & $87 \pm 8$ & $79 \pm 4$ & $71 \pm 9$ \\
\hline
\end{tabular}

increased temperatures generally cannot ensure impoved strength and stiffness of densified wood.

\section{CONCLUSION}

Pre-treatment of wood through immersion a 1:1 $\mathrm{CH}_{3} \mathrm{COOH}-\mathrm{H}_{2} \mathrm{O}_{2}$ solution at a concentration of $20 \%$ in water prior to densification increased the density and strength of densified pine wood and gmelina wood. The two densified wood species show different responses to increased treatment temperature and duration. Pine wood had better characteristics at the treatment condition of $150^{\circ} \mathrm{C}$ for 30 minutes, while gmelina wood had better characteristics at the treatment condition of $150^{\circ} \mathrm{C}$ for 15 minutes. These results suggest that the immersion and densification processes developed in this study enable to increased bending strengths, but the treatment temperature and duration should be adjusted based on the wood species being used.

\section{ACKNOWLEDGMENT}

The authors would like to thank the financial support of this research from Directorate General of Higher Education. Ministry of Education and Culture, Republic of Indonesia.

\section{REFERENCES}

Amin Y., Dwianto, W. 2006. Influence temperature and water vapor pressure to fixation compression wood using close system compression. (in Indonesia) Jurnal Ilmu dan Teknologi Kayu Tropis 4(2): 55-60.

ASTM International. 2005. Annual Book of ASTM standard. Volume 04.10, Wood. D 143 (2005). Standard Methods Test of Testing Small Clear Specimens of Wood. ASTM International, West Conshohocken, PA, USA.

British Standard. 1957. Methods of Testing Small Clear Specimens of Timber. Serial BS 373. British Standard Institution, London.

Danu, S., Mirzan, T.R., Dhedy, H., Darsono, Marsongko. 2013. Densification of Randu Wood (Ceiba pentandra L. Gaertn) and Surface with Compaction Ultra Violet Radiation (in Indonesia). Jurnal Sains Materi Indonesia 14(3): 222-228.

Darwis, A., Wahyudi, I., Cahyono, T.D. 2017. Densified wood anatomical structure and the effect of heat treatment on the recovery of set. Journal of the Indian Academy of Wood Science 14(1): 24-31. Frans, A.W. 2013. Adequate Pandanus Fiber (tectorius Lamk.) Boiling Time Using Forest Product Laboratory Method. [undergraduate thesis]. (in 
Indonesia). Faculty of Forestry in Papua, Manokwari. (Unpublished).

Hartono, R., Wahyudi, I., Febrianto, F., Dwianto, W., Hidayat, W., Jang, J.H., Lee, S.H., Park, S.H., Kim, N.H. 2016. Quality improvement of oil palm trunk properties by close system compression method. Journal of the Korean Wood Science and Technology 44(2): 172-183.

Hill, C.A.S. 2011. Wood modification: An update. Bioresources 6(2): 918-919.

Inoue, M., Sekino, N., Morooka, T., Rowell, R.M., Norimoto, M. 2008. Fixation of compressive deformation in wood by pre-steaming. Journal of Tropical Forest Science 20(4): 273-281.

Krisdianto, J., Balfas. 2005. Anatomical changes of Kekabu Wood (Bombaceiba. L) due to mechanical densification. Journal of Forestry Research 2(1): 27-36.

Krisdianto, J. 2006. Anatomical changes of light Coconut Wood Cocos nucifera L. due to steampress densification. Journal of Forest Products Research and Development Center 3(2): 83-92.

Kutnar, A., Sernek, M. 2007. Densification of wood. Zbornik gozdarstva in lesarstva 82: 53-62.

Lee, J.M., Lee, W.H. 2018. Dimensional stabilization trough heat treatment of thermally compressed wood of korean pine. Journal of the Korean Wood Science and Technology 46(5): 471-485.

Nestri, A.P. 2014. Effect of densification on physical and mechanical properties of fast growing teak wood (Tectona grandis L.f.). [undergraduate thesis]. Faculty of Forestry, Bogor Agricultural Institute, Bogor, Indonesia.
Panshin, A.J., de Zeeuw, C. 1980. Textbook of Wood Technology. Mc Graw-Hill Book Company. London.

Phebryanti, S. 2015. Coconut Wood as Raw Material for Furniture at House in Public Area. (in Indonesia) Journal Intra 3(1): 53-56.

Ratih, D, Wahyudi,I, Coto, Z. 2009. Enhancement Wood Quality from Community Forest with Densification and Impregnation with Oven as PreTreatment. (in Indonesia). Forest Products Research and Development Center. Bogor.

Rautkari, L. 2011. Thermo-Hydro-Mechanical Modification. Puu-28.4002 Wood Modification. Aalto University, Helsinki, Finland.

Sulistyono, Nugroho, N., Surjokusumo, S. 2003. Densification of wood engineering techniques II: physical and mechanical properties of agathis wood (Agathis lorantifolia Salisb.) densification in building construction wood. (in Indonesia) Bulletin Keteknikan Pertanian 17(1): 32-45.

Tomme, F., Girardet, F., Gfeller, B., and Navi, P. 1998. Densified wood: An innovative product with highly enhanced characters. In Proceedings of the 5th World Conference on Timber Engineering. Vol.2. Montreux-Lausanne, Switzerland.

Wahyudi, I. 2013. Relationship of Wood Anatomy Structure with Wood Properties, Utility, and its Processing. Research and Development of Indonesian Wood Anatomy Discussion. Bogor. Indonesia.

Wahyudi, I., Amin, Y., Darmawan, T., Adi, D.S., Kusumah, S.S., Dwianto, W. 2012. Density and strength distribution on compression wood at usage scale. In Proceedings Seminar Nasional Masyarakat Peneliti Kayu Indonesia XV. Pp. 156-164. 